Western University

Scholarship@Western

Biology Publications

Biology Department

$12-15-2012$

\title{
Reduced Translocation of Cadmium from Roots Is Associated with Increased Production of Phytochelatins and Their Precursors
}

Mst. Fardausi Akhter

Brian McGarvey

Sheila Macfie

smacfie@uwo.ca

Follow this and additional works at: https://ir.lib.uwo.ca/biologypub

Part of the Biology Commons

Citation of this paper:

Akhter, Mst. Fardausi; McGarvey, Brian; and Macfie, Sheila, "Reduced Translocation of Cadmium from Roots Is Associated with Increased Production of Phytochelatins and Their Precursors" (2012). Biology Publications. 44.

https://ir.lib.uwo.ca/biologypub/44 
Corresponding author:

\author{
Sheila M. Macfie \\ Department of Biology, Western University \\ London, ON, N6A 5B7, Canada \\ Tel: 1-519-661-2111 (×86487) \\ Fax: 519-661-3935 \\ E-mail: smacfie@uwo.ca
}


Reduced translocation of cadmium from roots is associated with increased production of phytochelatins and their precursors

\author{
Mst. Fardausi Akhter ${ }^{a}$ \\ Brian McGarvey ${ }^{\mathrm{b}}$ \\ Sheila M. Macfie ${ }^{* a}$
}

*corresponding author

${ }^{\text {a } D e p a r t m e n t ~ o f ~ B i o l o g y, ~ W e s t e r n ~ U n i v e r s i t y, ~ L o n d o n, ~ O N, ~ C a n a d a, ~ N 6 A ~ 5 B 7, ~}$

${ }^{b}$ Southern Crop Protection and Food Research Centre, Agriculture and Agri-Food Canada, London, ON, Canada N5V 4T3

DOI:10.1016/j.jplph.2012.07.011

(C) 2012. This manuscript version is made available under the CC-BY-NC-ND 4.0 license http://creativecommons.org/licenses/by-nc-nd/4.0/ 


\section{Summary}

Cadmium (Cd) is a non-essential trace element and its environmental concentrations are approaching toxic levels, especially in some agricultural soils. Understanding how and where Cd is stored in plants is important for ensuring food safety. In this study, we examined two plant species that differ in the distribution of Cd among roots and leaves. Lettuce and barley were grown in nutrient solution under two conditions: chronic (4 week) exposure to a low, environmentally relevant concentration $(1.0 \mu \mathrm{M})$ of Cd and acute $(1 \mathrm{~h})$ exposure to a high concentration $(5.0 \mathrm{mM})$ of $\mathrm{Cd}$. Seedlings grown in solution containing $1.0 \mu \mathrm{M} \mathrm{CdCl} 2$ did not show symptoms of toxicity and, at this concentration, $77 \%$ of the total Cd was translocated to leaves of lettuce, whereas only $24 \%$ of the total Cd was translocated to barley leaves. We tested the hypothesis that differential accumulation of $\mathrm{Cd}$ in roots and leaves is related to differential concentrations of phytochelatins (PCs), and its precursor peptides. The amounts of PCs and their precursor peptides in the roots and shoots were measured using HPLC. Each of PC $2-4$ was synthesized in the barley root upon chronic exposure to $\mathrm{Cd}$ and did not increase further upon

acute exposure. In the case of lettuce, no PCs were detected in the root given either Cd treatment. The high amounts of PCs produced in barley root could have contributed to preferential retention of Cd in barley roots.

Keywords: Cadmium; Hordeum vulgare; Lactuca sativa; Phytochelatin; Translocation 


\section{Introduction}

Phytochelatins (PCs) are enzymatically synthesized peptides in plants that usually consist of three amino acids: glutamic acid (Glu), cysteine (Cys) and glycine (Gly) (Kondo et al., 1984; Grill et al., 1985). The resultant glutathione (GSH) molecule ( $\gamma$-Glu-Cys)-Gly is transformed into PC by $\gamma$-glutamylcysteine dipeptidyl transpeptidase (phytochelatin synthase, EC 2.3.2.15), forming the general structural formula of ( $\gamma$-Glu-Cys) ${ }_{n}$-Gly, where n ranges from 2-11 (Grill et al., 1985; 1987; 1989). The carboxyl-terminal Gly is replaced with serine (Ser) in gramineae hydroxymethyl PCs (Klapheck et al., 1994), $\beta$-alanine ( $\beta$-Ala) in legume homo PCs (Grill et al., 1986), or can either be absent or replaced with Glu in maize (Zea mays, Meuwly et al., 1995). Phytochelatins are functionally analogous to metallothioneins (MTs), which are produced by animals and some fungi and have been identified in plants ranging from algae to monocots and dicots (Grill et al., 1987).

A number of metal ions are reported to be involved with activation of PC synthase in plants. These include the cations antimony $\left(\mathrm{Sb}^{5+}\right)$, bismuth $\left(\mathrm{Bi}^{3+}\right)$, cadmium $\left(\mathrm{Cd}^{2+}\right)$, copper $\left(\mathrm{Cu}^{2+}\right)$, gold $\left(\mathrm{Au}^{+}\right)$, lead $\left(\mathrm{Pb}^{2+}\right)$, mercury $\left(\mathrm{Hg}^{2+}\right)$, nickel $\left(\mathrm{Ni}^{2+}\right)$, silver $\left(\mathrm{Ag}^{+}\right)$, tin $\left(\mathrm{Sn}^{2+}\right)$ and zinc $\left(\mathrm{Zn}^{2+}\right)$ and the anions arsenate $\left(\mathrm{AsO}_{4}{ }^{3-}\right)$ and selenite $\left(\mathrm{SeO}_{3}{ }^{2-}\right)$ (Grill et al., 1987; 1988). Among these, the strongest activation of the enzyme was observed with $\mathrm{Cd}^{2+}$. The activity of PC synthase is selfregulated in that the product of the reaction (PC) chelates the enzyme-activating metal, thus terminating the enzyme reaction. Once PCs form complexes with metals they will either store the metal in metabolically inactive sites inside the cell (Salt and Rauser, 1995) or release them to apoenzymes, which require these metal ions as cofactors to perform their catalytic activity (Grill 
et al., 1988). Phytochelatins are thus not only involved in metal detoxification, but also metal homeostasis in plants.

Both PCs and their peptide precursors have a high affinity for metal cations because of the thiol (-SH) groups on the cysteine residues. A number of analytical techniques have been used for the identification and structural analysis of these metal-chelate complexes (Leopold and Günther, 1997; Scarano and Morelli, 2002; El-Zohri et al., 2005; Chekmeneva et al., 2007; 2008; 2011). In general, the interaction is governed by the binding affinity of thiol groups for metal ions (Chekmeneva et al., 2007; 2008) as well as the availability and complexing capacity of the ligands (Díaz-Cruz et al., 1997; 1998; Cruz et al., 2002; Kobayashi and Yoshimura, 2006; Chekmeneva et al., 2007; 2008).

The binding stoichiometry of the metal-PC $\mathrm{n}_{\mathrm{n}}$ complexes has also been studied (Díaz-Cruz et al., 1997; 1998; Kobayashi and Yoshimura, 2006; Chen et al., 2007; Chekmeneva et al., 2007; 2008; 2011). It was found that an increase in the number of thiol groups in a molecule produces an increase in the binding capacity, i.e. the number of metal ions that can be bound to a $\mathrm{PC}_{\mathrm{n}}$ molecule (Chekmeneva et al., 2011). Chen et al. (2007) studied $\mathrm{Cd}^{2+}-\mathrm{PC}_{\mathrm{n}}$ complexes from a Cd hyperaccumulator, Brassica chinensis, and reported the binding stoichiometries as 1:1 to 3:1 based on the availability of $\mathrm{Cd}^{2+}$ and thiol groups in the $\mathrm{Cd}^{2+}-\mathrm{PC}_{n}$ complexes in the cytosol.

The ability of metal-PC $\mathrm{n}_{\mathrm{n}}$ complexes to sequester metals in metabolically inactive sites depends on the stability of the complex. Chekmeneva et al. $(2007 ; 2008 ; 2011)$ measured stability constant values of $\mathrm{Cd}^{2+}-\mathrm{PC}_{\mathrm{n}}$ complexes using different techniques and concluded that the stability increases with higher chain lengths, up to $\mathrm{PC}_{3}$. Beyond $\mathrm{PC}_{3}$, the stability of the 
complexes stays the same due to the fact that four or more thiol groups can saturate the coordination number of $\mathrm{Cd}^{2+}$, which is usually tetrahedral.

Previous studies have reported Cd-induced PC synthesis (Grill et al., 1985; Ranieri et al., 2005; Wang and Wang, 2011) and identified $\mathrm{Cd}^{2+}-\mathrm{PC}_{\mathrm{n}}$ complexes either under laboratory conditions (Kobayashi and Yoshimura, 2006; Chekmeneva et al., 2007; 2008; 2011) or from plants in their native environment (Scarano and Morelli, 2002; Chen et al., 2007) as evidence for the proposed mechanism (Sanità di Toppi and Gabbrielli, 1999) involved in Cd detoxification in plants.

In this study we measured the total amount of thiol-containing PCs and their precursors produced in the roots and shoots of lettuce and barley and used the binding stoichiometries of possible $\mathrm{Cd}^{2+}-\mathrm{PC}_{\mathrm{n}}$ complexes to estimate the theoretical efficiency of thiol-containing molecules in binding $\mathrm{Cd}^{2+}$ to understand the role of PCs and their precursors against differential Cd accumulation in barley and lettuce. The plant species were chosen because, in a previous experiment, lettuce and barley seedlings showed consistent differences in the proportions of the total Cd taken up in the plant that were translocated to the shoot. When grown in hydroponic nutrient solution containing 0.10 to $2.0 \mu \mathrm{M} \mathrm{Cd}$, the proportions of $\mathrm{Cd}$ translocated to the shoots ranged from $19.0 \pm 0.2 \%$ to $25.2 \pm 4.9 \%$ in barley and from $78.1+4.2 \%$ to $90.0 \pm 1.4 \%$ in lettuce (Akhter and Macfie, 2012). The mechanisms that control Cd translocation have not yet been determined. In lettuce and barley (Akhter and Macfie, 2012), rice (Oryza sativa, Uraguchi et al., 2009) and maize (Florijn and Beusichem, 1993) increased translocation of Cd to the shoots in some plants could not be explained by greater volumes of water transpired. Uraguchi et al. (2009) measured higher concentrations of Cd in the xylem of rice with increased translocation of Cd but neither those plants nor varieties of durum wheat (Triticum turgidum var. durum, Adeniji 
et al., 2010) with higher concentrations of Cd in the shoots took up more Cd from the growth medium than did the varieties with less Cd in the shoots. Increased translocation of Cd from the roots appears to be related to increased xylem loading and/or decreased retention of Cd in the roots. Complexation of $\mathrm{Cd}^{2+}$ with $\mathrm{PC}_{\mathrm{n}}$ or their precursor complexes (Cys, Glu, and $\gamma$-Glu-Cys) in roots could contribute to reduced xylem loading and reduced translocation. Thus, the hypothesis that differential accumulation of $\mathrm{Cd}$ in roots and leaves of barley and lettuce is associated with differential concentrations of phytochelatin $\left(\mathrm{PC}_{2-4}\right)$ and its precursor peptides was tested in this study.

\section{Materials and methods}

\section{Chemicals}

Chemicals, stock solutions and reagents used were of analytical grade. Diethylenetriaminepentaacetic acid (DTPA), 4-(2-hydroxyethyl)-piperazine-1-propane sulfonic acid (HEPPS), Nacetyl-L-cysteine (NAC), glutathione (GSH), $\gamma$-glutamylcysteine ( $\gamma$-Glu-Cys or $\gamma$-EC), Lcysteine (Cys), Tris(2-carboxyethyl)phosphine hydrochloride (TCEP), monobromobimane (MBrB), methanesulfonic acid (MSA), and trifluoroacetic acid (TFA) were obtained from Sigma-Aldrich (Oakville, ON, Canada); hydrochloric acid (HCl) and acetonitrile (ACN) were obtained from Caledon (Georgetown, ON, Canada). Phytochelatin standards for $\mathrm{PC}_{2}, \mathrm{PC}_{3}$ and $\mathrm{PC}_{4}$, each with $\geq 95 \%$ purity, were obtained from AnaSpec (Fremont, CA, USA), who used solid phase peptide synthesis to generate the PCs. Phytochelatins $2-4$ were chosen for analysis because they form the primary $\mathrm{Cd}^{2+}-\mathrm{PC}_{\mathrm{n}}$ complexes in plants (Scarano and Morelli, 2002; Chen et al., 2007; Sadi et al., 2008). All solvents and ACN were filtered with a $0.45 \mu \mathrm{m}$ filter (Type HA, Millipore Corporation, Etobicoke, ON, Canada). Water was purified by a Milli-Q system. All 
glassware was washed in soapy tap water, rinsed in tap water, soaked in $10 \%(\mathrm{v} / \mathrm{v})$ hydrochloric acid overnight, rinsed in deionized RO (reverse osmosis) water and air-dried before use.

\section{Germination and growth conditions}

Leaf lettuce (Lactuca sativa L. cv. Grand Rapids) and barley (Hordeum vulgare L. cv. CDC McGwire, hulless 2-row feed barley) seeds were placed on moist (RO water) filter paper in Petri dishes and placed in the dark at room temperature. When the radicles were approximately $1 \mathrm{~cm}$ long (24 - 36 h), seedlings were transferred to sand-filled pots and watered with nutrient solution adjusted to $\mathrm{pH}$ 6.0. The nutrient solution contained $1.0 \mathrm{mM} \mathrm{Ca}\left(\mathrm{NO}_{3}\right)_{2} \cdot 4 \mathrm{H}_{2} \mathrm{O}, 1.0 \mathrm{mM} \mathrm{K} \mathrm{HPO}_{4}$, $0.4 \mathrm{mM} \mathrm{KNO}_{3}, 0.3 \mathrm{mM} \mathrm{Mg}\left(\mathrm{NO}_{3}\right)_{2} \cdot 6 \mathrm{H}_{2} \mathrm{O}, 0.3 \mathrm{mM} \mathrm{NH}_{4} \mathrm{NO}_{3}, 0.1 \mathrm{mM} \mathrm{K}_{2} \mathrm{SO}_{4}, 10.0 \mu \mathrm{M}$ $\mathrm{FeCl}_{3} \cdot 6 \mathrm{H}_{2} \mathrm{O}, 10.0 \mu \mathrm{M} \mathrm{Na}{ }_{2} \mathrm{EDTA}, 6.0 \mu \mathrm{M} \mathrm{H}_{3} \mathrm{BO}_{3}, 2.0 \mu \mathrm{M} \mathrm{MnCl}_{2} \cdot 4 \mathrm{H}_{2} \mathrm{O}, 0.50 \mu \mathrm{M} \mathrm{ZnSO}_{4} \cdot 7 \mathrm{H}_{2} \mathrm{O}$, $0.15 \mu \mathrm{M} \mathrm{CuSO}_{4} \cdot 5 \mathrm{H}_{2} \mathrm{O}$ and $0.10 \mu \mathrm{M} \mathrm{Na}_{2} \mathrm{MoO}_{4}$.

Potted seedlings were kept in a growth chamber set to $21^{\circ} \mathrm{C}, 60 \%$ relative humidity, and a $16 \mathrm{~h}$ day length. The light intensity was $187 \pm 1.5 \mu \mathrm{mol} \mathrm{m}^{-2} \mathrm{~s}^{-1}$. The seedlings were transferred to $1.4 \mathrm{~L}$ glass jars after 1 week in sand culture. Two seedlings were secured in the lid of a jar with a $0.5 \times$ $1 \times 6 \mathrm{~cm}$ piece of foam, and each jar was covered with black cloth to prevent algal growth. The jars were filled with nutrient solution to which either $0(\mathrm{n}=3)$ or $1.0 \mu \mathrm{M} \mathrm{CdCl}_{2} \cdot 5 \mathrm{H}_{2} \mathrm{O}$ (hereafter referred to as $\mathrm{CdCl}_{2}, \mathrm{n}=6$ ) was added, and the $\mathrm{pH}$ was adjusted to 6.0 using concentrated $\mathrm{HCl}$. Each jar was connected to an aeration system and the plants were provided with fresh nutrient solution (including the corresponding Cd treatment) every second day. On the $28^{\text {th }}$ day in hydroponic culture, seedlings from three of the $1.0 \mu \mathrm{M} \mathrm{CdCl}_{2}$ treatments were moved into new jars of aerated nutrient solution with $5.0 \mathrm{mM} \mathrm{CdCl}_{2}(\mathrm{pH} \mathrm{6.0)}$ for $1 \mathrm{~h}$. At harvest, the roots were 
separated from the shoots from one plant in each jar, rinsed in $\mathrm{RO}$ water and oven dried $\left(60^{\circ} \mathrm{C}\right)$ to constant weight and stored for Cd analysis. The Cd measured in these roots represented the total amount accumulated. The $\mathrm{Cd}$ in the apoplast of the roots from the other plant was desorbed using $\mathrm{CaCl}_{2}$ (Buckley et al., 2010, with some modifications). Specifically, the roots were rinsed in RO water and transferred to $900 \mathrm{~mL}$ of $5.0 \mathrm{mM} \mathrm{CaCl}_{2}$ at $0^{\circ} \mathrm{C}$ (ice water bath) for $30 \mathrm{~min}$. After 30 min of desorption, the roots were separated from the shoots, rinsed in RO water and oven dried $\left(60^{\circ} \mathrm{C}\right)$ to constant weight and stored for Cd analysis. The amount of $\mathrm{Cd}$ in these tissues represented the amount in the symplast. Control seedlings were treated with the same procedure except that $\mathrm{RO}$ water was used instead of $\mathrm{CaCl}_{2}$. The amount of $\mathrm{Cd}$ in the apoplast was calculated as apoplastic Cd = total Cd - symplastic Cd. As a control check, the concentration of $\mathrm{Cd}$ in the $\mathrm{CaCl}_{2}$ wash was also measured.

In another experiment, a separate batch of seedlings was grown following the same procedures mentioned above except that individual seedlings were transferred to glass jars. At harvest, fresh weights of roots and shoots were recorded and a $1.0 \mathrm{~g}$ subsample of each tissue type was flash frozen in liquid nitrogen and stored at $-80^{\circ} \mathrm{C}$ for PC analysis. The remainder of the root and shoot samples were oven dried $\left(60^{\circ} \mathrm{C}\right)$ to constant weight and stored for Cd analysis.

\section{Extraction of thiol-containing molecules}

Thiol-containing compounds were extracted following the method of Sneller et al. (2000) with some modifications. Frozen $\left(-80^{\circ} \mathrm{C}\right)$ root and shoot samples were ground in liquid nitrogen $\left(\mathrm{N}_{2}\right)$ using a mortar and pestle, and $0.10 \mathrm{~g}$ of each sample was immediately placed in an individual microcentrifuge tube containing $1.5 \mathrm{~mL}$ of $6.3 \mathrm{mM}$ DTPA with $0.1 \%$ (v/v) TFA and $25 \mu \mathrm{L}$ of 20 $\mathrm{mM}$ TCEP $\left(4^{\circ} \mathrm{C}\right)$. The mixture was sonicated in ice water (Cole-Parmer ultrasonic system, model 
no. 8893-21, Montreal, QC, Canada) for 25 min and the supernatant was collected after centrifugation at $15000 \times \mathrm{g}$ for $60 \mathrm{~min}$ at $4^{\circ} \mathrm{C}$. The thiol groups were derivatized (see section Derivatization of thiol groups) immediately and analyzed using HPLC (see section HPLC instrumentation and chromatographic conditions). The unused portion of each sample was returned to the $-80^{\circ} \mathrm{C}$ freezer.

\section{Preparation of thiol-containing standards}

Standards and reactant solutions were prepared according to the procedure described in Minocha et al. (2008) with some modifications. Stock solutions of $1 \mathrm{mM}$ of each thiol-containing standard (Cys, Glu, $\gamma$-Glu-Cys, $\mathrm{PC}_{2}, \mathrm{PC}_{3}, \mathrm{PC}_{4}$ and NAC [N-acetyl-cysteine], an internal standard), were prepared using deionised water (RO water) and stored in the dark at $-20^{\circ} \mathrm{C}$. The internal standard was necessary because duplicate measurements of each standard had peak areas that varied by up to $3 \%$. Adjusting the NAC value for each standard and experimental sample to a pre-determined value ensured that this instrument variability did not affect quantification of thiol-containing molecules. The pre-determined value was equal to the average NAC peak area obtained for three independent NAC samples.

The concentrations used to prepare standard curves and establish detection limits ranged from 0 to $200 \mu \mathrm{M}$ for Cys, $\gamma$-Glu-Cys, GSH, $\mathrm{PC}_{2}$, and $\mathrm{PC}_{3}$ and 0 to $100 \mu \mathrm{M}$ for $\mathrm{PC}_{4}$. At concentrations higher than $100 \mu \mathrm{M}$, the chromatographic peaks for $\mathrm{PC}_{4}$ were off-scale. To make the series of standards, the stock solutions were diluted with $6.3 \mathrm{mM}$ DTPA with $0.1 \% \mathrm{v} / \mathrm{v}$ TFA (extraction buffer). Thiol-containing standards were prepared fresh on the day of use, derivatized immediately (see section Derivatization of thiol groups) and analyzed using HPLC (see section HPLC instrumentation and chromatographic conditions). Thiol-containing molecules were 
quantified using five-point calibration curves (Table 1). The slope for $\mathrm{PC}_{2}$ was lower than expected. Repeated preparation of this component resulted in consistently low slope values, which indicates that the molecule may have degraded (oxidized). If this was the case, then the calculated concentrations of $\mathrm{PC}_{2}$ in our experimental samples might be slightly higher than the actual values; however, the relative amounts of $\mathrm{PC}_{2}$ among our experimental treatments would be unaffected. A standard mixture containing monothiols (Cys, $\gamma$-EC and GSH), NAC and polythiols $\left(\mathrm{PC}_{2}, \mathrm{PC}_{3}\right.$ and $\left.\mathrm{PC}_{4}\right)$ was also run.

\section{Derivatization of thiol groups}

The thiol-containing compounds were derivatizated with $\mathrm{MBrB}$ following the procedures of Rijstenbil and Wijnholds (1996) and Sneller et al. (2000), as described in Minocha et al. (2008). HEPPS buffer (200 mM) was prepared in $6.3 \mathrm{mM}$ DTPA set to $\mathrm{pH}$ 8.2. Then, $615 \mu \mathrm{L}$ of this solution was mixed with $25 \mu \mathrm{L}$ of $20 \mathrm{mM}$ TCEP solution, which was prepared fresh each day of use in 1M HEPPS buffer and used as a reducing agent in the reaction mixture. To this mixture, samples or standards $(250 \mu \mathrm{L})$ as well as NAC $(10 \mu \mathrm{L}$ of $0.5 \mathrm{mM})$ were added and the mixture was pre-incubated at $45^{\circ} \mathrm{C}$. After $10 \mathrm{~min}, \mathrm{MBrB}$ was added (10 $\mu \mathrm{L}$ of $50 \mathrm{mM} \mathrm{MBrB}$, which was prepared in ACN and kept in the dark at $4^{\circ} \mathrm{C}$ until use) to the mixture and the tube was placed the dark at $45^{\circ} \mathrm{C}$ for an additional 30 min. The reaction was terminated by adding $100 \mu \mathrm{L}$ of $1 \mathrm{M}$ MSA. The solution was filtered $(0.2 \mu \mathrm{m})$ before HPLC analysis.

\section{HPLC instrumentation and chromatographic conditions}

The HPLC instrument used was an Agilent Technologies 1200 series system with the following components: G1311A quaternary pump, G1322A degasser, G1367B auto sampler, G1330B 
FC/ALS Therm, G1315D diode array detector (DAD), G1321B fluorescence detector (FLD), and Chemstation software. The column used was a $\mathrm{C}_{30}$, YMC-Carotenid ${ }^{\mathrm{TM}}$ column with $3 \mu \mathrm{m}$ particle size ( $4.6 \mathrm{~m} \times 250 \mathrm{~mm}$, Waters). The injection volume was $50 \mu \mathrm{L}$. The excitation and emission wavelengths were set at 390 and $490 \mathrm{~nm}$, respectively. Thiol-containing molecules were separated by using two solvents: (A) $0.1 \%$ TFA in RO water and (B) ACN. The details of the gradient profile are given in Table 2. Total runtime for each sample was 60 min including column cleaning. The flow rate was set at $1 \mathrm{~mL} \min ^{-1}$ throughout the runtime. The detection limit (3× average noise level) was calculated from the lowest concentration of each standard visible in the chromatogram (Table 1). Finally, data were integrated using Chemstation software.

Estimation of $\mathrm{Cd}^{2+}$-thiol-complexation

We estimated the capacity for thiol-containing molecules to bind $\mathrm{Cd}^{2+}$ ions in the samples. This was done based on the measured amounts of $\mathrm{Cd}^{2+}$, PCs and PC-precursors as well as the expected ratios of $\mathrm{Cd}^{2+}$ and PCs in the potential $\mathrm{Cd}^{2+}-\mathrm{PC}_{\mathrm{n}}$ complexes. The ratios used were 1:1 for $\mathrm{Cd}^{2+}-\mathrm{Cys}, \mathrm{Cd}^{2+}-(\gamma-\mathrm{Glu}-\mathrm{Cys})$ and $\mathrm{Cd}^{2+}-\mathrm{GSH}, 2: 1$ for $\mathrm{Cd}^{2+}-\mathrm{PC}_{2}$ and 3:1 for $\mathrm{Cd}^{2+}-\mathrm{PC}_{3-4}($ Chen et al., 2007; Chekmeneva et al., 2011).

\section{Cadmium content}

Root and shoot samples were acid-digested using a modified EPA test method SW-846 (US EPA 2005). Dried samples were hand-chopped then ground using a mortar and pestle. Each $0.10 \mathrm{~g}$ subsample was placed in a $15 \mathrm{~mL}$ glass test tube with $1 \mathrm{~mL}$ pure nitric acid (OmniTrace ${ }^{\circledR}$, EM Science, USA) covered with a glass marble, which prevented evaporation yet allowed pressure to be released. The efficiency of the acid-digestion procedure was assessed by similarly 
processing a standard reference material (SRM) from the National Institute of Standards and Technology (NIST 1573a, tomato leaves) and possible Cd contamination was assessed by processing reagent blanks. Samples were digested overnight at room temperature. The following day, samples were heated to $90-100^{\circ} \mathrm{C}$ on a hot plate until the vapours became transparent. After cooling to room temperature, samples were filtered (VWR, qualitative grade 413) then brought to $50 \mathrm{~mL}$ with RO water. The samples were analyzed for Cd content by inductively-coupled plasma atomic emission spectrometry (ICP-AES) using the following conditions: Perkin-Elmer Optima 3300 Dual view ICP-AES; RF generator power, 1300 Watts; plasma flow rate, $15 \mathrm{~L} \mathrm{~min}^{-}$ 1; auxiliary flow rate, $0.5 \mathrm{~L} \mathrm{~min}^{-1}$; nebulizer flow rate, $0.8 \mathrm{~L} \mathrm{~min}{ }^{-1}$; pump flow rate, $1.0 \mathrm{~L} \mathrm{~min}^{-1}$; analyte line, Cd 226.507 nm; plasma view, axial. The detection limit (3× average noise level) was $0.001 \mathrm{ppm}$ for $\mathrm{Cd}$. The percentage recovery of Cd in the digested SRM was $74 \pm 8 \%$ and no Cd was detected in the reagent blanks.

\section{Statistical analysis}

One-way ANOVA followed by Tukey tests were used to detect significant $(p<0.05)$ effects of Cd treatment on Cd content and thiol compound content in the shoot and root tissues and for differences between apoplast and symplast Cd content. The coefficient of determination $\left(\mathrm{R}^{2}\right)$ was calculated and used to assess the precision of each standard curve for the thiol compounds. Graphics and statistical analyses were done in SigmaPlot (version 11.0). 


\section{Results}

\section{Cadmium content}

Plants grown in control solution did not contain measureable amounts of Cd, except for roots of barley in which Cd was just above the detection limit (Table 3). Low concentrations (0.09 to $\left.0.33 \mathrm{mg} \mathrm{g}^{-1}\right)$ and amounts ( 0.07 to $\left.0.45 \mathrm{mg}\right)$ of Cd were measured in shoots and roots of barley and lettuce from the $1.0 \mu \mathrm{M} \mathrm{CdCl}_{2}$ treatment, with roots having 1.5- to 2-fold higher concentrations than shoots. When plants were exposed to $5.0 \mathrm{mM} \mathrm{CdCl}$ for $1 \mathrm{~h}$ prior to harvest, concentrations of Cd in shoots increased by 50\% in barley and 25\% in lettuce, while concentrations of $\mathrm{Cd}$ in roots increased 5-fold in barley and 50-fold in lettuce, compared to plants from the $1.0 \mu \mathrm{M} \mathrm{CdCl}$ treatments. The patterns were similar for the total amount of $\mathrm{Cd}$ (amount $=\mathrm{Cd}$ concentration $\times$ biomass); amounts of Cd increased in response to the $5.0 \mathrm{mM}$ $\mathrm{CdCl}_{2}$ treatment and roots contained higher concentrations of Cd than did shoots.

The two species differed in their relative translocation of $\mathrm{Cd}$ to shoots. In the $1.0 \mu \mathrm{M} \mathrm{CdCl}_{2}$ treatment (Table 3), barley stored $76 \%$ of total Cd in the root and translocated only $24 \%$ to the shoot; in contrast, lettuce stored only $23 \%$ of the total Cd in the root and translocated the rest to the shoot. Regardless of the species, plants stored 90\% of the total Cd in the root when exposed to $5.0 \mathrm{mM} \mathrm{CdCl}_{2}$ for $1 \mathrm{~h}$; however, at the end of this treatment barley plants appeared healthy and stood straight whereas lettuce plants lost vigour and wilted.

\section{Apoplastic and symplastic Cd}

After desorption of $\mathrm{Cd}$ from the apoplast, the concentrations of $\mathrm{Cd}$ remaining in plants grown with a chronic, low concentration of Cd were below the detection limit of the ICP-AES (data not 
shown), thus plants given the acute exposure to $5.0 \mathrm{mM} \mathrm{CdCl}_{2}$ were used to estimate the distribution of Cd within the roots. Because proportionally more Cd might be expected to be in the apoplast of plants given an acute exposure to a very high concentration of $\mathrm{Cd}$, the amounts of symplastic Cd for the plants from the $1.0 \mu \mathrm{M} \mathrm{CdCl}_{2}$ treatment in Table 5 are likely to be underestimates. Concentrations of Cd were higher in lettuce roots compared to barley roots (Fig. 1a). In lettuce, the Cd concentration was 2-fold higher in the apoplast compared to symplast, whereas no difference was detected in barley (Fig. 1a). When the total amount of Cd in each root compartment was calculated, there were no differences in total Cd accumulation between the species (Fig. 1b), each accumulated about $0.5 \mathrm{mg}$ Cd. In barley, Cd was evenly distributed between the apoplast and symplast whereas lettuce stored only $35 \%$ of the total root $\mathrm{Cd}$ in the symplast and the rest was bound within the apoplast (Fig. 1b).

\section{HPLC profile of thiol-containing compounds}

The $\mathrm{C}_{30}$ column used in this study improved the resolution of peaks compared to other MBrBbased derivatization methods that used a $\mathrm{C}_{18}$ column (e.g., Minocha et al., 2008; Thangavel et al., 2007). Identification of the components was confirmed by spiking the reaction blank and standard mixture with individual components, one at a time. A very broad reagent peak was observed in the chromatograms at approximately $28 \mathrm{~min}$. This peak was also observed in other MBrB-based derivatization studies (e.g., Thangavel et al., 2007; Minocha et al., 2008). Kawakami et al. (2006) identified this peak as tetramethylbimane $\left(\mathrm{Me}_{4} \mathrm{~B}\right)$ and reported that this compound was used during the synthesis of $\mathrm{MBrB}$.

Monothiols and PCs in plant tissues 
The total amount of each monothiol and PC in the shoot and root tissues was calculated by multiplying the concentration of each thiol-containing compound by the corresponding tissue mass (Table 4, with trends summarized in Fig. 2). In barley shoots, the amounts of Cys, GSH and $\mathrm{PC}_{4}$ were lowest in plants exposed to $1.0 \mu \mathrm{M} \mathrm{CdCl}_{2}$ for 4 weeks. When the same plants were exposed to $5.0 \mathrm{mM} \mathrm{CdCl}_{2}$ for $1 \mathrm{~h}$ prior to harvest, the amounts of Cys, GSH and $\mathrm{PC}_{4}$ returned to control values. For all treatments, the total amount of $\mathrm{PC}_{4}$ in the shoots was very low. Cadmium treatment did not affect the amounts of $\gamma$-EC in the shoots. Each of $\mathrm{PC}_{2}$ and $\mathrm{PC}_{3}$ were below the detection limit in barley shoots.

In barley roots grown in control solution, all monothiols (except GSH) and PCs were below the detection limit (Table 4, with trends summarized in Fig. 2). The amounts of GSH in barley did not vary with $\mathrm{Cd}$ treatment but each of Cys, $\gamma$-EC, $\mathrm{PC}_{2}, \mathrm{PC}_{3}$ and $\mathrm{PC}_{4}$ increased in response to $\mathrm{Cd}$. The amounts were the same for plants in the $1.0 \mu \mathrm{M} \mathrm{CdCl}_{2}$ treatment and the $5.0 \mathrm{mM} \mathrm{CdCl}_{2}$ treatment, except for Cys. Plants synthesized five times more Cys when exposed to $5.0 \mathrm{mM}$ $\mathrm{CdCl}_{2}$ for $1 \mathrm{~h}$ prior to harvest.

Lettuce shoots contained high amounts of Cys and GSH when grown in control solution and, as in barley, the amounts were lower in plants from the $1.0 \mu \mathrm{M} \mathrm{CdCl}_{2}$ treatment (Table 4, with trends summarized in Fig. 2). However, unlike in barley, the amounts of Cys and GSH did not return to control values after the acute $5.0 \mathrm{mM} \mathrm{CdCl}_{2}$ treatment. Similar to barley, the amounts of $\gamma$-EC, $\mathrm{PC}_{2}$ and $\mathrm{PC}_{3}$ were below detection limit and a very low amount of $\mathrm{PC}_{4}$ was measured in lettuce shoots.

Only Cys and GSH were detected in roots of lettuce (Table 4, with trends summarized in Fig. 2). There were no effects of Cd treatment on Cys production. GSH was reduced in plants in the 1.0 
$\mu \mathrm{M} \mathrm{CdCl} 2$ treatment compared to the control plants and returned to the control value after the 5.0 $\mathrm{mM} \mathrm{CdCl} 2$ treatment (Table 4).

The total amount of thiol-containing compounds in control plants was higher in barley $(29.9+4.8$ $\mu \mathrm{mol})$ than in lettuce $(17.7 \pm 2.1 \mu \mathrm{mol})$; barley contained higher amounts of $\gamma$-EC and GSH but lower amounts of Cys relative to lettuce (Table 4). Phytochelatins were below detection limit in lettuce root, whereas barley root synthesized PCs upon Cd exposure. It thus appears that barley was more efficient in synthesizing thiol-containing molecules compared to lettuce.

Estimating the formation of $\mathrm{Cd}^{2+}$-thiol complexes

Phytochelatins are synthesized in the root symplast and can bind $\mathrm{Cd}^{2+}$ in this compartment only. Based on the results of the apoplast-symplast study (Fig. 1), the total number of moles of Cd in the root and the moles of Cd theoretically present in the symplast of barley and lettuce root were calculated (Table 5). We then calculated the maximum number of moles of $\mathrm{Cd}^{2+}$ that could theoretically be chelated by the PCs as well as the monothiols that were measured in the barley and lettuce roots (using data from Table 4). The ability of thiol groups to bind $\mathrm{Cd}^{2+}$ was calculated based on published information on the binding stoichiometry of $\mathrm{Cd}^{2+}-\mathrm{PC}_{\mathrm{n}}$ complexes (Cruz et al., 2002; Chekmeneva et al. 2007; 2008; 2011). We assumed that all of the Cd estimated to be in the symplast was available to interact with all of the thiol groups and that no other types of molecules formed a complex with Cd. While this is no doubt an overestimate of the actual amount of $\mathrm{Cd}^{2+}$-available for complexation, it provides an estimate of the maximum potential for $\mathrm{Cd}^{2+}$ to form complexes with PCs and their precursors. We determined that PCs had the potential to chelate as much as $100 \%$ of the symplastic $\mathrm{Cd}^{2+}$ in barley roots exposed to 1.0 $\mu \mathrm{M} \mathrm{CdCl}_{2}$ for 28 days (Table 5). When the same plants were exposed to $5.0 \mathrm{mM} \mathrm{CdCl}_{2}$ for $1 \mathrm{~h}$ 
prior to harvest, thiol-containing compounds could form complexes with only $46 \%$ of the total amount of symplastic $\mathrm{Cd}^{2+}$. When monothiols were included as potential $\mathrm{Cd}^{2+}$ chelators, $100 \%$ $\left(1.0 \mu \mathrm{M} \mathrm{CdCl}_{2}\right)$ and $85 \%\left(5.0 \mathrm{mM} \mathrm{CdCl}_{2}\right)$ of the symplastic $\mathrm{Cd}^{2+}$ could have been chelated with thiol-containing molecules. In the case of lettuce, no PCs were detected under experimental conditions and only monothiols were present (Table 5). At $1.0 \mu \mathrm{M} \mathrm{CdCl}_{2}$, these monothiols could theoretically form complexes with $100 \%$ of the total symplast $\mathrm{Cd}^{2+}$ in the lettuce root. For the lettuce exposed to $5.0 \mathrm{mM} \mathrm{CdCl}_{2}$ for $1 \mathrm{~h}$, synthesis of monothiols was unchanged and the efficiency of complexation with $\mathrm{Cd}^{2+}$ dropped to $5 \%$.

\section{Discussion}

The potential role of $\mathrm{PC}_{2-4}$ and their precursor peptides in differential Cd accumulation in lettuce and barley was tested in the present study by growing plants under two conditions: chronic (28 d) exposure to a low, environmentally relevant concentration $(1.0 \mu \mathrm{M})$ of $\mathrm{Cd}$ and acute $(1 \mathrm{~h})$ exposure to a high concentration (5.0 mM) of Cd. Chronic exposure was used to evaluate the 'steady state' status of the various peptides under mild Cd stress; acute exposure was used to evaluate the initial response to potential Cd toxicity.

\section{Differential Cd accumulation}

The distribution of Cd differs between lettuce and barley. When grown with a chronic, low concentration of Cd only $24 \%$ of the total Cd taken up by lettuce was retained in the root, whereas $76 \%$ of the total Cd in barley was retained in the root. This confirms our previous report of differential translocation of Cd in these two species (Akhter and Macfie, 2012). When plants were exposed to a very high concentration of $\mathrm{Cd}$ for $1 \mathrm{~h}$, over $90 \%$ of the total Cd was found in the root for both species, likely reflecting lack of time for the Cd to be translocated to the shoot. 
The species also differed in the localization of Cd within the root. Approximately two thirds of the total Cd taken up by lettuce roots from the acute Cd treatment was in the loosely bound (apoplast) fraction. In contrast, Cd in barley roots was evenly distributed between the apoplast and symplast. Thus, these species provide a good system in which to examine the role of metalbinding molecules in differential translocation of Cd.

\section{Phytochelatins}

The synthesis of PCs in response to Cd has been reported in a number of studies conducted on various species including a marine diatom (Thalassiosira nordenskioeldii, Wang and Wang, 2011), freshwater green alga (Scenedesmus vacuolatus, Le Faucheur et al., 2005), tobacco cell culture (Nicotiana tabacum, Zitka et al., 2011), bread wheat (Triticum aestivum, Ranieri et al., 2005), rice (Nocito et al., 2011) and broad bean (Vicia faba, Čabala et al., 2011). The fact that no PCs were detected in the roots of lettuce grown in either Cd treatment indicates that PCs were not involved in $\mathrm{Cd}^{2+}$ chelation and accumulation in lettuce root. In contrast to our results, Maier et al. (2003) reported PCs in concentrations of $\sim 0.10 \mu \mathrm{mol} \mathrm{g}^{-1}$ fresh weight in roots of romaine lettuce (L. sativa var longifolia) upon exposure to $25 \mathrm{nM} \mathrm{CdCl}_{2}$. It is possible that PCs in our samples degraded during sample preparation; we extracted PCs from frozen tissue (liquid nitrogen followed by storage at $-80^{\circ} \mathrm{C}$ ) rather than immediately harvested tissue, and Maier et al. (2003) showed that up to 50\% of the PCs can be lost during freezing.

Most of the Cd taken up by lettuce was translocated to the shoot. However, low amounts ( $\leq 0.3$ $\mu$ mol) of only one $\mathrm{PC}, \mathrm{PC}_{4}$, were detected in lettuce shoots making it unlikely that PCs were a major contributor to $\mathrm{Cd}^{2+}$ detoxification in the shoot either. Maier et al. (2003) also reported low 
concentrations of total PCs in romaine lettuce shoots ( $\sim 0.02$ to $0.25 \mu \mathrm{mol} \mathrm{g}{ }^{-1}$ fresh weight) exposed to Cd. The PCs in control plants may have been produced in response to the $\mathrm{Zn}^{2+}$ and $\mathrm{Cu}^{2+}$ in the nutrient solution. Along with $\mathrm{Cd}^{2+}$, these metal ions can also induce the synthesis of PCs (Grill et al., 1987). The amounts of PCs synthesized in response to nutrient cations are expected to be low but it was surprising that we detected only $\mathrm{PC}_{4}$ in plants from control and $\mathrm{CdCl}_{2}$ treatments. We expect that $\mathrm{PC}_{2}$ was also present in lettuce leaves but was below detection limit. Under our conditions, the detection limit for $\mathrm{PC}_{2}$ was 10 -fold higher than for $\mathrm{PC}_{4}$ and, since $\mathrm{PC}_{4}$ has three thiol groups and $\mathrm{PC}_{2}$ has only one, $\mathrm{PC}_{4}$ is more easily detected when using MBrB derivatization. Maier et al. (2003) also reported PCs ( 0.02 $\mu \mathrm{mol} \mathrm{g}{ }^{-1}$ fresh weight) in roots of romaine lettuce grown in control (Cd-free) solution. However, they reported the concentrations in terms of $\gamma$-Glu-Cys equivalents; thus, the type of PC in their lettuce was not identified.

In contrast to lettuce, $\mathrm{PC}_{2-4}$ were synthesized in the barley root upon chronic exposure to $1.0 \mu \mathrm{M}$ $\mathrm{CdCl}_{2}$, with the relative amounts of $\mathrm{PC}_{2}$ being 1-2 orders of magnitude higher than those of $\mathrm{PC}_{3}$ and $\mathrm{PC}_{4}$. Similarly, Wang and Wang (2011) found that $\mathrm{PC}_{2}$ was synthesized quickly as a response to Cd exposure in marine diatom Thalassiosira nordenskioeldii and it was six times higher than $\mathrm{PC}_{3}$ and $\mathrm{PC}_{4}$. Sadi et al. (2008) studied $\mathrm{Cd}^{2+}-\mathrm{PC}_{\mathrm{n}}$ complexes in Arabidopsis thaliana and reported $\mathrm{Cd}^{2+}-\mathrm{PC}_{2}$ as the primary complex in wild as well as in genetically modified PCdeficient mutant lines. We believe that the high amounts of PCs produced in barley root could have contributed to reduced translocation of Cd to barley shoots relative to lettuce shoots, which in turn could explain why barley leaves appeared healthy after $1 \mathrm{~h}$ exposure to $5.0 \mathrm{mM} \mathrm{CdCl} 2$ whereas lettuce leaves were visibly negatively affected. Persson et al. (2006) demonstrated the 
biological importance of $\mathrm{Cd}^{2+}-\mathrm{PC}_{\mathrm{n}}$ complexation for tolerance towards $\mathrm{Cd}$ using two genotypes of barley. They showed that although the total tissue concentration of Cd was similar for both genotypes, the tolerant genotype synthesized significantly more $\mathrm{Cd}^{2+}-\mathrm{PC}_{\mathrm{n}}$ complexes than the intolerant genotype. Since it is assumed that $\mathrm{Cd}^{2+}-\mathrm{PC}_{n}$ complexes transport $\mathrm{Cd}$ to the root vacuole (Sanità di Toppi and Gabbrielli, 1999) their formation would reduce the amounts of Cd available for translocation to aboveground tissues.

The amounts of PCs in barley did not increase further upon exposure to $5.0 \mathrm{mM} \mathrm{CdCl}_{2}$ for $1 \mathrm{~h}$ prior to harvest. This could be explained by the substrate availability required for PC synthesis. When plants are exposed to Cd, protein degradation provides the amino acids necessary for PC synthesis (Wu et al., 2004). It is possible that the amino acid pool remained unchanged during the short, $1 \mathrm{~h}$ treatment, thus preventing increased production of PCs.

\section{Precursor peptides}

Since Cys, $\gamma$-EC and GSH are precursors of PC biosynthesis, their amounts are expected to drop (even if only temporarily) upon acute exposure to $\mathrm{Cd}^{2+}$, and might be expected to increase or return to control values under chronic exposure to $\mathrm{Cd}^{2+}$ if they are required to supply ongoing synthesis of PCs. In our study, the amounts of $\gamma$-EC were either low or below detection limit in all samples and the relative amounts of Cys and GSH varied with both species and tissue type. Roots of both species contained about an order of magnitude less Cys as compared to shoots and there was no consistent response to either chronic or acute exposure to Cd. In general, the amount of GSH was reduced in plants grown with chronic exposure to Cd. A number of other studies also reported reduced GSH level upon days or weeks of exposure to Cd (Scheller et al., 1987; Tukendorf and Rauser, 1990; Lima et al., 2006). However, like PCs, the amounts of GSH 
returned to control levels in plants given the acute $5.0 \mathrm{mM} \mathrm{CdCl}_{2}$ treatment, indicating that GSH synthesis was rapidly up-regulated, possibly to meet the requirement for PC synthesis or to combat Cd-induced stress. The exception to this was in the lettuce shoots, where the amount of GSH stayed low upon acute exposure to Cd. Other than its role in PC synthesis, GSH is also known to form complexes with $\mathrm{Cd}^{2+}$. Dameron et al. (1989) isolated GSH-coated CdS crystallites in Candida glabrata providing direct evidence of biologically formed $\mathrm{Cd}^{2+}$-GSH complexes. Recently Chekmeneva et al. (2011) used isothermal titration calorimetry (ITC) to understand the influence of PC chain length on the $\mathrm{Cd}^{2+}-\mathrm{PC}_{\mathrm{n}}$ complex stabilities and showed that GSH can form stable $\mathrm{Cd}^{2+}$-GSH complexes at pH 7.5 and 8.5. However, since $\mathrm{Cd}^{2+}-\mathrm{PC}_{\mathrm{n}}$ complexes are more stable than $\mathrm{Cd}^{2+}$ - GSH complexes, it is likely that GSH will play a minor role in detoxifying $\mathrm{Cd}^{2+}$ compared to PCs. It has been suggested that GSH might act as a first line of defense against $\mathrm{Cd}^{2+}$ toxicity by complexing metal ions before sufficient PCs are synthesized (Thangavel et al., 2007). Once PCs take over the detoxification process, GSH gets involved in a secondary defense mechanism by scavenging free radicals in $\mathrm{Cd}^{2+}$-induced oxidative stress (Gallego et al., 2005; Ranieri et al., 2005). Thus, GSH is not only a precursor for PC synthesis (Grill et al., 1989) but also an important antioxidant in plants. In the present study, the amount of GSH was always higher in barley, probably contributing to higher chelation of $\mathrm{Cd}^{2+}$ compared to lettuce.

$C d^{2+}-P C_{n}$ complex formation

Higher concentrations and amounts of PCs and their precursors in barley root compared to lettuce root indicate that the formation of $\mathrm{Cd}^{2+}$-peptide complexes probably contributes to the observed retention of $\mathrm{Cd}$ in barley roots. While our calculations of symplastic $\mathrm{Cd}^{2+}$ might be 
overestimates (due to chelation of $\mathrm{Cd}^{2+}$ with other molecules), and some of the PCs in our samples may have degraded, we determined there were sufficient PCs in the roots of barley from the chronic $1.0 \mu \mathrm{M} \mathrm{CdCl}_{2}$ treatment to bind $100 \%$ of the putative symplastic $\mathrm{Cd}^{2+}$. If the amounts of $\mathrm{Cd}^{2+}$ in the symplast were actually lower than we estimated and if the amounts of PCs were actually higher than we measured, then $\mathrm{Cd}^{2+}-\mathrm{PC}_{n}$ complexes could effectively eliminate free $\mathrm{Cd}^{2+}$ in the symplast. In barley roots from the acute $5.0 \mathrm{mM} \mathrm{CdCl}_{2}$ treatment, PCs could, in theory, form complexes with only $46 \%$ of the symplastic $\mathrm{Cd}^{2+}$ but if $\mathrm{Cd}^{2+}$ also formed complexes with monothiols then only $15 \%$ of the symplastic $\mathrm{Cd}^{2+}$ would be predicted to be free ions. In the case of lettuce, PCs were not synthesized but $100 \%$ of the total symplastic Cd could theoretically form complexes with the monothiols produced in the roots upon exposure to 1.0 $\mu \mathrm{M} \mathrm{CdCl}$. The estimated proportion of chelated $\mathrm{Cd}^{2+}$ drops to $5 \%$ in lettuce roots from the 5.0 $\mathrm{mM} \mathrm{CdCl}_{2}$ treatment. However, we do not expect $\mathrm{Cd}^{2+}$-monothiol formation to be as efficient as our estimates indicate and the lack of PCs in lettuce roots could explain the higher proportion of total Cd that is translocated to lettuce leaves.

If Sanità di Toppi and Gabbrielli’s (1999) model is correct, after $\mathrm{Cd}^{2+}$ is released from a PC complex in the vacuole, the PCs could either be degraded by vacuolar hydrolysis or could return back to the cytoplasm. These apo-PCs could serve as a shuttle, bringing more $\mathrm{Cd}^{2+}$ into the vacuole. This shuttling process could continue until all the free $\mathrm{Cd}^{2+}$ are moved into the vacuole. Based on our estimates, each PC produced in barley roots exposed to the acute, high concentration of Cd would have to carry only $4 \mathrm{Cd}^{2+}$ ions into the vacuole to sequester the amount of Cd estimated in the root symplast. Previously, the role of PCs was thought to be limited to the intracellular detoxification mechanism by shuttling $\mathrm{Cd}^{2+}-\mathrm{PC}_{\mathrm{n}}$ complexes into the vacuole. However, recent studies on Brassica napus (Mendoza- Cózatl et al., 2008) and 
Arabidopsis thaliana (Gong et al., 2003; Chen et al., 2006) showed that PCs could also play a major role in long-distance transport of $\mathrm{Cd}^{2+}$ through xylem and phloem. Mendoza- Cózatl et al. (2008) found that the concentration of PCs was 50 times higher in the phloem sap compared to the xylem sap and concluded that phloem was more active in transporting $\mathrm{Cd}^{2+}$ from the source (older leaves) to the sink tissues (root, branches, younger leaves). This seems reasonable because the $\mathrm{pH}$ in phloem sap is basic compared to the xylem sap (Shelp, 1987) and would allow greater stability of $\mathrm{Cd}^{2+}-\mathrm{PC}_{\mathrm{n}}$ complexes. So, it is possible that $\mathrm{Cd}$ might be transported within the plant as $\mathrm{Cd}^{2+}$-thiol complexes rather than as free ions. In our study, more PCs as well as their precursors were measured in the shoots of barley compared to lettuce and it is possible that these PCs formed complexes with shoot $\mathrm{Cd}^{2+}$ and transported it downwards to the roots. This could be another reason for our observation that a greater proportion of the Cd in barley was found in the root whereas more of the Cd in lettuce was found in the shoot.

Finally it can be said that there appears to be a relationship between PC synthesis in the root and Cd translocation to the shoot in barley and lettuce. Between the species, barley had higher concentrations and amounts of PCs and their precursors compared to lettuce and barley retained more Cd in the roots. However, until direct measures of sub-cellular Cd-distribution and Cdspeciation are available it is difficult to definitively determine the role of PC and its precursors in binding $\mathrm{Cd}^{2+}$ in the roots. Further studies are needed to confirm the role of PCs and their precursors in answering the differences in Cd accumulation between barley and lettuce.

\section{Acknowledgements}

The research was financed by the Natural Sciences and Engineering Council of Canada Discovery Grant Program. The authors also gratefully acknowledge Bob Pocs for assistance with 
HPLC. 


\section{References}

Adeniji BA, Budimir-Hussey MT, Macfie SM. Production of organic acids and adsorption of Cd on roots of durum wheat (Triticum turgidum L. var. durum). Acta Physiol Plant 2010; 32: 1063-72.

Akhter MF, Macfie SM. Species-specific relationship between transpiration and cadmium translocation in lettuce, barley and radish. J Plant Stud 2012; 1: 2-13.

Buckley WT, Buckley KE, Huang J. Root cadmium desorption methods and their evaluation with compartmental modeling. New Phytol 2010; 188: 280-90.

Čabala R, Slováková L, El Zohri M, Frank H. Accumulation and translocation of Cd metal and the Cd-induced production of glutathione and phytochelatins in Vicia faba L. Acta Physiol Plant 2011; 33: 1239-48.

Chekmeneva E, Díaz-Cruz JM, Ariño C, Esteban M. Binding of $\mathrm{Cd}^{2+}$ and $\mathrm{Zn}^{2+}$ with the phytochelatin ( $\gamma$-Glu-Cys) ${ }_{4}$-Gly: A voltammetric study assisted by multivariate curve resolution and electrospray ionization mass spectrometry. Electroanalysis 2007; 19: 310-17.

Chekmeneva E, Prohens R, Díaz-Cruz JM, Ariño C, Esteban M. Thermodynamics of $\mathrm{Cd}^{2+}$ and $\mathrm{Zn}^{2+}$ binding by the phytochelatin ( $\gamma$-Glu-Cys) ${ }_{4}$-Gly and its precursor glutathione. Anal Biochem 2008; 375: 82-9. 
Chekmeneva E, Gusmão R, Díaz-Cruz JM, Ariño C, Esteban M. From cysteine to longer chain thiols: A thermodynamic analysis of cadmium binding by phytochelatins and their fragments. Metallomics 2011; 3: 838-46.

Chen A, Komives EA, Schroeder JI. An improved grafting technique for mature Arabidopsis plants demonstrates long-distance shoot-to-root transport of phytochelatins in Arabidopsis. Plant Physiol 2006; 141: 108-20.

Chen L, Guo Y, Yang L, Wang Q. SEC-ICP-MS and ESI-MS/MS for analyzing in vitro and in vivo Cd-phytochelatin complexes in a Cd-hyperaccumulator Brassica chinensis. J Anal At Spectrom 2007; 22: 1403-8.

Cruz BH, Diaz-Cruz JM, Sestakova I, Velek J, Arino C, Esteban M. Differential pulse voltammetric study of the complexation of Cd (II) by the phytochelatin ( $\gamma$-Glu-Cys ) ${ }_{2}$-Gly assisted by multivariate curve resolution. J Electroanal Chem 2002; 520: 111-8.

Dameron CT, Smith B R, Winges, DR. Glutathione-coated cadmium-sulfide crystallites in Candida glabrata. J Biol Chem 1989; 264: 17355-60.

Díaz-Cruz MS, Mendieta J, Tauler R, Esteban M. Cadmium-binding properties of glutathione: A chemometrical analysis of voltammetric data. J Inorg Biochem 1997; 66: 29-36.

Díaz-Cruz MS, Mendieta J, Monjonell A, Tauler R, Esteban M. Study of the zinc-binding properties of glutathione by differential pulse polarography and multivariate curve resolution. J Inorg Biochem 1998; 70: 91-8. 
El-Zohri MHA, Čabala R, Frank H. Quantification of phytochelatins in plants by reversed-phase HPLC-ESI-MS-MS. Anal Bioanal Chem 2005; 382: 1871-6.

Florijn PJ, Beusichem MLV.Uptake and distribution of cadmium in maize inbred lines. Plant Soil 1993; 150, 25-32.

Gallego SM, Kogan MJ, Azpilicueta CE, Peña C, Tomaro ML. Glutathione-mediated antioxidative mechanisms in sunflower (Helianthus Annuus L.) cells in response to cadmium stress. Plant Growth Regul 2005; 46: 267-76.

Gong JM, Lee DA, Schroeder JI. Long-distance root-to-shoot transport of phytochelatins and cadmium in Arabidopsis. Proc Natl Acad Sci USA 2003; 100: 10118-23.

Grill E, Winnacker EL, Zenk MH. Phytochelatins: The principal heavy-metal complexing peptides of higher plants. Science 1985; 230: 674-6.

Grill E, Gekeler W, Winnacker E, Zenk HH. Homo-phytochelatins are heavy metal-binding peptides of homo-glutathione containing Fabales. Fed Eur Biochem Soc 1986; 205: 47-50.

Grill E, Winnacker EL, Zenk MH. Phytochelatins, a class of heavy-metal-binding peptides from plants, are functionally analogous to metallothioneins. Proc Natl Acad Sci USA 1987; 84: 439-43.

Grill E, Thumann J, Winnacker EL, Zenk MH. Induction of heavy-metal binding phytochelatins by inoculation of cell cultures in standard media. Plant Cell Rep 1988; 7: 375-8. 
Grill E, Loffler S, Winnacker EL, Zenk MH. Phytochelatins, the heavy-metal-binding peptides of plants, are synthesized from glutathione by a specific $\gamma$-glutamylcysteine dipeptidyl transpeptidase ( phytochelatin synthase ). Proc Natl Acad Sci USA 1989; 86: 6838-42.

Kawakami SK, Gledhill M, Achterberg EP. Determination of phytochelatins and glutathione in phytoplankton from natural waters using HPLC with fluorescence detection. Trends Anal Chem 2006; 25: 133-42.

Klapheck S, Fliegner W, Zimmer I. Hydroxymethyl-phytochelatins [( $\gamma$-glutamylcysteine $)_{n^{-}}$ serine] are metal-induced peptides of the poaceae. Plant Physiol 1994; 104: 1325-32.

Kobayashi R, Yoshimura E. Differences in the binding modes of phytochelatin to cadmium (II) and zinc (II) ions. Biol Trace Elem Res 2006; 114: 313-8.

Kondo N, Inai K, Isobe M, Goto T. Cadystin A and B: Major unit peptides comprising cadmium binding peptides induced in fission yeast separation, revision of structures and synthesis. Tetrahedron Lett 1984; 25: 3869-72.

Le Faucheur S, Behra R, Sigg L. Phytochelatin induction, cadmium accumulation, and algal sensitivity to free cadmium ion in Scenedesmus vacuolatus. Environ Toxicol Chem 2005; 24: $1731-7$.

Leopold I, Günther D. Investigation of the binding properties of heavy-metal-peptide complexes in plant cell cultures using HPLC-ICP-MS. Fresenius J Anal Chem 1997; 359: 364-70. 
Lima AIG, Pereira SIA, de Almeida Paula Figueira EM, Caldeira GCN, de Matos Caldeira HDQ. Cadmium detoxification in roots of Pisum sativum seedlings: Relationship between toxicity levels, thiol pool alterations and growth. Environ Exp Bot 2006; 55: 149-62.

Maier EA, Matthews RD, McDowell JA, Walden RR, Ahner BA. Environmental cadmium levels increase phytochelatin and glutathione in lettuce grown in a chelator-buffered solution. J Environ Qual 2003; 32:1356-64.

Mendoza-Cózatl DG, Butko E, Springer F, Torpey JW, Komives EA, Kehr J et al. Identification of high levels of phytochelatins, glutathione and cadmium in the phloem sap of Brassica napus. A role for thiol-peptides in the long-distance transport of cadmium and the effect of cadmium on iron translocation. Plant J 2008; 54: 249-59.

Meuwly P, Thibault P, Schwen AL, Rauser, WE. Three families of thiol peptides are induced by cadmium in maize. Plant J 1995; 7: 391-400.

Minocha R, Thangavel P, Dhankher OP, Long S. Separation and quantification of monothiols and phytochelatins from a wide variety of cell cultures and tissues of trees and other plants using high performance liquid chromatography. J Chromatogr A 2008; 1207: 72-83.

Nocito FF, Lancilli C, Dendena B, Lucchini G, Sacchi, GA. Cadmium retention in rice roots is influenced by cadmium availability, chelation and translocation. Plant Cell Environ 2011; 34: 994-1008. 
Persson DP, Hansen TH, Holm PE, Schjoerring JK, Hansen HCB, Nielsen J et al. Multielemental speciation analysis of barley genotypes differing in tolerance to cadmium toxicity using SEC-ICP-MS and ESI-TOF-MS. J Anal At Spectrom 2006; 21: 996-1005.

Ranieri A, Castagna A, Scebba F, Careri M, Zagnoni I, Predieri G et al. Oxidative stress and phytochelatin characterisation in bread wheat exposed to cadmium excess. Plant Physiol Biochem 2005; 43: 45-54.

Rijstenbil JW, Wijnholds JA. HPLC analysis of nonprotein thiols in planktonic diatoms: Pool size , redox state and response to copper and cadmium exposure. Marine Biol 1996; 127: 45-54.

Sadi BBM, Vonderheide AP, Gong JM, Schroeder JI, Shann JR, Caruso JA. An HPLC-ICP-MS technique for determination of cadmium-phytochelatins in genetically modified Arabidopsis thaliana. J Chromatogr B 2008; 861: 123-9.

Salt DE, Rauser WE. MgATP-dependent transport of phytochelatins across the tonoplast of oat roots. Plant Physiol 1995; 107: 1293-1301.

Sanità di Toppi L, Gabbrielli R. Response to cadmium in higher plants. Environ Exp Bot 1999; 41: 105-30.

Scarano G, Morelli E. Characterization of cadmium-and lead-phytochelatin complexes formed in a marine microalga in response to metal exposure. Biometals 2002; 15: 145-51.

Scheller HV, Huang B, Hatch E, Goldsbrough PB. Phytochelatin synthesis and glutathione levels in response to heavy metals in tomato cells. Plant Physiol 1987; 85: 1031-5. 
Shelp BJ. The composition of phloem exudate and xylem sap from broccoli (Brassica oleracea var. italica) supplied with $\mathrm{NH}_{4}{ }^{+}, \mathrm{NO}_{3}{ }^{-}$or $\mathrm{NH}_{4} \mathrm{NO}_{3}$. J Exp Bot 1987; 38: 1619-36.

Sneller FEC, van Heerwaarden LM, Koevoets PLM, Vooijs R, Schat H, Verkleij JAC. Derivatization of phytochelatins from Silene vulgaris, induced upon exposure to arsenate and cadmium: comparison of derivatization with Ellman's reagent and Monobromobimane. J Agric Food Chem 2000; 48: 4014-9.

Thangavel P, Long S, Minocha R. Changes in phytochelatins and their biosynthetic intermediates in red spruce (Oicea rubens Sarg.) cell suspension cultures under cadmium and zinc stress. Plant Cell Tissue Organ Cult 2007; 88: 201-16.

Tukendorf A, Rauser WE. Changes in glutathione and phytochelatins in roots of maize seedlings exposed to cadmium. Plant Sci 1990; 70: 155-66.

Uraguchi S, Mori S, Kuramata M, Kawasaki A, Arao T, Ishikawa S. Root-to-shoot Cd translocation via the xylem is the major process determining shoot and grain cadmium accumulation in rice. J Exp Bot 2009; 60: 2677-88.

US EPA (United States Environmental Protection Agency) (2005), Test methods for evaluating solid waste, physical/chemical methods, series 3000. [Online] Available: http://www.epa.gov/epaoswer/hazwaste/test/main.htm/ (Jan 4, 2012)

Wang MJ, Wang WX. Cadmium sensitivity, uptake, subcellular distribution and thiol induction in a marine diatom: Exposure to cadmium. Aquat Toxicol 2011; 101: 377-86. 
Wu FB, Chen F, Wei K, Zhang GP. Effect of cadmium on free amino acid, glutathione and ascorbic acid concentrations in two barley genotypes (Hordeum vulgare L.) differing in cadmium tolerance. Chemosphere 2004; 57: 447-54.

Zitka O, Krystofova O, Sobrova P, Adam V, Zehnalek J, Beklova M, Kizek R. Phytochelatin synthase activity as a marker of metal pollution. J Hazard Mater 2011; 192: 794-800. 
Table 1

Linear ranges, $\mathrm{r}^{2}$ and slope values for standard curves of the thiol compounds

\begin{tabular}{lllll}
\hline $\begin{array}{l}\text { Component } \\
\text { name }\end{array}$ & $\begin{array}{l}\text { Detection limit } \\
\left(\mathrm{nmol} 50 \mu \mathrm{L}^{-1}\right)\end{array}$ & $\begin{array}{l}\text { Linear range } \\
\left(\mathrm{nmol} 50 \mu \mathrm{L}^{-1}\right)\end{array}$ & $\begin{array}{l}\text { Coefficient of } \\
\text { determination, } \mathrm{r}^{2}\end{array}$ & slope \\
\hline Cys & 0.02 & $0-1.67$ & 0.99 & 44.39 \\
$\mathrm{GSH}$ & 0.02 & $0-1.67$ & 0.99 & 26.67 \\
$\gamma$-EC & 0.02 & $0-1.67$ & 0.99 & 25.68 \\
$\mathrm{PC}_{2}$ & 0.10 & $0-1.67$ & 0.99 & 4.88 \\
$\mathrm{PC}_{3}$ & 0.01 & $0-1.67$ & 0.98 & 79.63 \\
$\mathrm{PC}_{4}$ & 0.01 & $0-0.83$ & 0.94 & 73.32 \\
\hline
\end{tabular}

Table 2

Solvent gradient profile used in the separation of MBrB-derivatized thiols using HPLC

\begin{tabular}{lll} 
Time & Solvent A (by volume) & Solvent B (by volume) \\
$(\min )$ & $(0.1 \%$ TFA) & $(\mathrm{ACN})$ \\
\hline 0.1 & 95.0 & 5.0 \\
40.0 & 70.0 & 30.0 \\
41.0 & 40.0 & 60.0 \\
45.0 & 0 & 100.0 \\
55.0 & 0 & 100.0 \\
56.0 & 95.0 & 5.0 \\
60.0 & 95.0 & 5.0 \\
\hline
\end{tabular}


Table 3

Concentration and amount of $\mathrm{Cd}$ in barley and lettuce grown in different $\mathrm{Cd}$ treatments. Plants were grown with 0 or $1.0 \mu \mathrm{M} \mathrm{CdCl} \mathrm{H}_{2}$ for $28 \mathrm{~d}$. Half of the plants grown with Cd were transferred to $5.0 \mathrm{mM} \mathrm{CdCl}_{2}$ for $1 \mathrm{~h}$ immediately prior to harvest. Within each tissue, different lower case letters indicate significant differences in Cd concentration and Cd accumulation, as determined by post hoc Tukey tests $(p<0.05)$. Values are mean (SE), $\mathrm{n}=3$ for each treatment, $\mathrm{dl}=$ detection limit.

\begin{tabular}{|c|c|c|c|c|c|c|c|c|c|}
\hline & \multirow[t]{2}{*}{ Cd treatment } & \multicolumn{4}{|c|}{ Barley } & \multicolumn{4}{|c|}{ Lettuce } \\
\hline & & \multicolumn{2}{|l|}{ Shoot } & \multicolumn{2}{|l|}{ Root } & \multicolumn{2}{|l|}{ Shoot } & \multicolumn{2}{|l|}{ Root } \\
\hline \multirow{5}{*}{$\begin{array}{c}\mathrm{Cd} \\
\text { concentration } \\
\left(\mathrm{mg} \mathrm{g}^{-1}\right)\end{array}$} & No Cd & \multicolumn{2}{|l|}{$<\mathrm{dl} \mathrm{a}$} & \multicolumn{2}{|c|}{$0.004(0.001) \mathrm{a}$} & \multicolumn{2}{|l|}{$<\mathrm{dl} \mathrm{a}$} & \multicolumn{2}{|l|}{$<\mathrm{dl} \mathrm{a}$} \\
\hline & $1.0 \mu \mathrm{M}$ & \multicolumn{2}{|c|}{$0.085(0.010) \mathrm{b}$} & \multicolumn{2}{|c|}{$1.177(0.010) \mathrm{b}$} & \multicolumn{2}{|c|}{$0.206(0.011) b$} & \multicolumn{2}{|c|}{$0.326(0.026) \mathrm{a}$} \\
\hline & $5.0 \mathrm{mM}$ & \multicolumn{2}{|c|}{$0.133(0.002) \mathrm{c}$} & \multicolumn{2}{|c|}{$6.339(0.459) \mathrm{c}$} & \multicolumn{2}{|c|}{$0.268(0.007) \mathrm{c}$} & \multicolumn{2}{|c|}{$15.46(0.599) \mathrm{b}$} \\
\hline & \multirow{2}{*}{$\begin{array}{l}\text { One-way } \\
\text { ANOVA }\end{array}$} & $p$ & $F_{(2,8)}$ & $p$ & $F_{(2,8)}$ & $p$ & $F_{(2,8)}$ & $p$ & $F_{(2,8)}$ \\
\hline & & 0.001 & 130.86 & 0.001 & 33.51 & 0.001 & 295.26 & 0.001 & 670.71 \\
\hline & 0 & $<\mathrm{dl} \mathrm{a}$ & & 0.003 & $.001) \mathrm{a}$ & $<\mathrm{dl} \mathrm{a}$ & & $<\mathrm{dl} \mathrm{a}$ & \\
\hline \multirow[t]{5}{*}{ Total Cd (mg) } & $1.0 \mu \mathrm{M}$ & \multicolumn{2}{|c|}{$0.142(0.012) b$} & \multicolumn{2}{|c|}{$0.448(0.036) \mathrm{a}$} & \multicolumn{2}{|c|}{$0.223(0.037) b$} & \multicolumn{2}{|c|}{$0.065(0.012) \mathrm{a}$} \\
\hline & $5.0 \mathrm{mM}$ & \multicolumn{2}{|c|}{$0.243(0.011) \mathrm{c}$} & \multicolumn{2}{|c|}{$2.325(0.368) \mathrm{b}$} & \multicolumn{2}{|c|}{$0.259(0.013) \mathrm{b}$} & \multicolumn{2}{|c|}{$3.032(0.319) \mathrm{b}$} \\
\hline & \multirow[t]{2}{*}{$\begin{array}{l}\text { One-way } \\
\text { ANOVA }\end{array}$} & $p$ & $F_{(2,8)}$ & $p$ & $F_{(2,8)}$ & $p$ & $F_{(2,8)}$ & $p$ & $F_{(2,8)}$ \\
\hline & & 0.001 & 168.70 & 0.001 & 33.51 & 0.001 & 34.74 & 0.001 & 93.43 \\
\hline & & & & & 33 & & & & \\
\hline
\end{tabular}




\begin{tabular}{lccc}
\hline $\begin{array}{l}\text { \% of total Cd } \\
\text { retained in the }\end{array}$ & No Cd & $<\mathrm{dl}$ & $<\mathrm{dl}$ \\
root & $1.0 \mu \mathrm{M}$ & $76(1.7)$ & $23(1.2)$ \\
& $5.0 \mathrm{mM}$ & $90(0.9)$ & $92(0.4)$ \\
\hline
\end{tabular}


Table 4

Molar amounts of phytochelatins ( $\mathrm{PC}_{2}, \mathrm{PC}_{3}$, and $\mathrm{PC}_{4}$ ) and their precursor monothiols (Cys, $\gamma$-EC, and GSH) in the shoot and root tissue extracts of barley and lettuce exposed to different Cd treatments. Plants were grown with 0 or 1.0 $\mu \mathrm{M} \mathrm{CdCl}_{2}$ for $28 \mathrm{~d}$. Half of the plants grown with Cd were transferred to $5.0 \mathrm{mM} \mathrm{CdCl}_{2}$ for $1 \mathrm{~h}$ immediately prior to harvest. Within each thiol-containing molecule, different lower case letters indicate significant differences in amounts, as determined by post-hoc Tukey tests $(P<0.05)$. Values are mean $(\mathrm{SE}), \mathrm{n}=3$ for each treatment, dl=detection limit.

\begin{tabular}{|c|c|c|c|c|c|c|c|c|c|c|c|c|c|}
\hline Tissue & Cd treatment & \multicolumn{2}{|c|}{ Cys $(\mu \mathrm{mol})$} & \multicolumn{2}{|c|}{$\gamma$-EC $(\mu \mathrm{mol})$} & \multicolumn{2}{|c|}{ GSH ( $\mu$ mol) } & \multicolumn{2}{|c|}{$\mathrm{PC}_{2}(\mu \mathrm{mol})$} & \multicolumn{2}{|c|}{$\mathrm{PC}_{3}(\mu \mathrm{mol})$} & \multicolumn{2}{|c|}{$\mathrm{PC}_{4}(\mu \mathrm{mol})$} \\
\hline \multirow{5}{*}{ 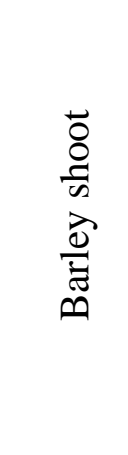 } & No Cd & \multicolumn{2}{|c|}{$5.74(0.80) b$} & \multicolumn{2}{|c|}{$0.99(0.24) \mathrm{a}$} & \multicolumn{2}{|c|}{$20.10(3.29) b$} & \multicolumn{2}{|l|}{$<\mathrm{dl}$} & \multicolumn{2}{|l|}{$<\mathrm{dl}$} & \multicolumn{2}{|c|}{$0.27(0.03) b$} \\
\hline & $1 \mu \mathrm{M} \mathrm{Cd}$ & \multicolumn{2}{|c|}{$1.79(0.12) \mathrm{a}$} & \multicolumn{2}{|c|}{$0.51(0.03) \mathrm{a}$} & \multicolumn{2}{|c|}{$8.00(0.08) \mathrm{a}$} & \multicolumn{2}{|l|}{$<\mathrm{dl}$} & \multicolumn{2}{|l|}{$<\mathrm{dl}$} & \multicolumn{2}{|c|}{$0.13(0.02) \mathrm{a}$} \\
\hline & $5 \mathrm{mM} \mathrm{Cd}$ & \multicolumn{2}{|c|}{$5.93(0.11) b$} & \multicolumn{2}{|c|}{0.79 (0.19) a } & \multicolumn{2}{|c|}{$14.75(0.23) a b$} & \multicolumn{2}{|l|}{$<\mathrm{dl}$} & \multicolumn{2}{|l|}{$<\mathrm{dl}$} & \multicolumn{2}{|c|}{$0.26(0.01) b$} \\
\hline & \multirow{2}{*}{$\begin{array}{l}\text { One-way } \\
\text { ANOVA }\end{array}$} & $p$ & $F_{(2,8)}$ & $p$ & $F_{(2,8)}$ & $p$ & $F_{(2,8)}$ & & & & & $p$ & $F_{(2,8)}$ \\
\hline & & 0.001 & 24.59 & 0.24 & 1.84 & 0.01 & 10.13 & & & & & 0.007 & 13.07 \\
\hline \multirow{5}{*}{ 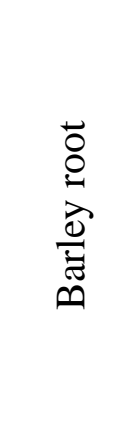 } & No Cd & \multicolumn{2}{|l|}{$<\mathrm{dl} \mathrm{a}$} & \multicolumn{2}{|l|}{$<\mathrm{dl} \mathrm{a}$} & \multicolumn{2}{|c|}{$2.83(0.42) \mathrm{a}$} & \multicolumn{2}{|l|}{$<\mathrm{dl} \mathrm{a}$} & \multicolumn{2}{|l|}{$<\mathrm{dl} \mathrm{a}$} & \multicolumn{2}{|l|}{$<\mathrm{dl} \mathrm{a}$} \\
\hline & $1 \mu \mathrm{M} \mathrm{Cd}$ & \multicolumn{2}{|c|}{$0.20(0.04) b$} & \multicolumn{2}{|c|}{$0.72(0.09) \mathrm{b}$} & \multicolumn{2}{|c|}{2.09 (0.19) a } & \multicolumn{2}{|c|}{$1.60(0.15) b$} & $0.05(($ & 1) b & 0.11( & ) b \\
\hline & $5 \mathrm{mM} \mathrm{Cd}$ & $0.91(C$ & 9) c & 0.74 & 08) b & 2.70 & 5) a & 2.31( & $.24) \mathrm{c}$ & 0.05( & 03) b & 0.12( & ) b \\
\hline & One-way & $p$ & $F_{(2,8)}$ & $p$ & $F_{(2,8)}$ & $p$ & $F_{(2,8)}$ & $p$ & $F_{(2,8)}$ & $p$ & $F_{(2,8)}$ & $p$ & $F_{(2,8)}$ \\
\hline & & 0.001 & 70.73 & 0.001 & 36.77 & 0.22 & 1.99 & 0.001 & 52.44 & 0.002 & 22.93 & 0.001 & 66.49 \\
\hline
\end{tabular}




\begin{tabular}{|c|c|c|c|c|c|c|c|c|c|c|}
\hline \multirow{5}{*}{ 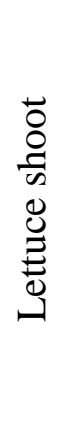 } & No Cd & \multicolumn{2}{|c|}{$8.60(0.87) b$} & $<\mathrm{dl}$ & \multicolumn{2}{|c|}{8.35 (1.14) b } & $<\mathrm{dl}$ & $<\mathrm{dl}$ & \multicolumn{2}{|c|}{$0.18(0.01) b$} \\
\hline & $1 \mu \mathrm{M} \mathrm{Cd}$ & \multicolumn{2}{|c|}{$3.05(0.50) \mathrm{a}$} & $<\mathrm{dl}$ & \multicolumn{2}{|c|}{$3.95(0.54)$ a } & $<\mathrm{dl}$ & $<\mathrm{dl}$ & \multicolumn{2}{|c|}{$0.09(0.02) \mathrm{a}$} \\
\hline & $5 \mathrm{mM} \mathrm{Cd}$ & \multicolumn{2}{|c|}{$3.89(0.01) \mathrm{a}$} & $<\mathrm{dl}$ & \multicolumn{2}{|c|}{$3.34(0.05) \mathrm{a}$} & $<\mathrm{dl}$ & $<\mathrm{dl}$ & \multicolumn{2}{|c|}{$0.30(0.004) \mathrm{c}$} \\
\hline & \multirow{2}{*}{$\begin{array}{l}\text { One-way } \\
\text { ANOVA }\end{array}$} & $p$ & $F_{(2,8)}$ & & $p$ & $F_{(2,8)}$ & & & $p$ & $F_{(2,8)}$ \\
\hline & & 0.01 & 26.66 & & 0.005 & 14.07 & & & 0.001 & 64.54 \\
\hline \multirow{5}{*}{ 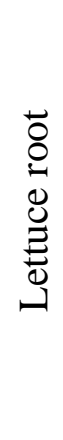 } & No Cd & \multicolumn{2}{|c|}{$0.13(0.01) \mathrm{a}$} & $<\mathrm{dl}$ & \multicolumn{2}{|c|}{$0.44(0.06) b$} & $<\mathrm{dl}$ & $<\mathrm{dl}$ & $<\mathrm{dl}$ & \\
\hline & $1 \mu \mathrm{M} \mathrm{Cd}$ & \multicolumn{2}{|c|}{$0.26(0.01) \mathrm{a}$} & $<\mathrm{dl}$ & \multicolumn{2}{|c|}{$0.21(0.03) \mathrm{a}$} & $<\mathrm{dl}$ & $<\mathrm{dl}$ & $<\mathrm{dl}$ & \\
\hline & $5 \mathrm{mM} \mathrm{Cd}$ & \multicolumn{2}{|c|}{$0.09(0.004) \mathrm{a}$} & $<\mathrm{dl}$ & \multicolumn{2}{|c|}{$0.39(0.001) b$} & $<\mathrm{dl}$ & $<\mathrm{dl}$ & $<\mathrm{dl}$ & \\
\hline & \multirow{2}{*}{$\begin{array}{l}\text { One-way } \\
\text { ANOVA }\end{array}$} & $p$ & $F_{(2,8)}$ & & $p$ & $F_{(2,8)}$ & & & & \\
\hline & & 0.059 & 4.73 & & 0.01 & 9.75 & & & & \\
\hline
\end{tabular}


Table 5

Estimated amounts of $\mathrm{Cd}^{2+}$ that could be complexed with the thiol-containing molecules in the symplast of roots of barley and lettuce. Total Cd includes both apoplastic and symplastic Cd. Symplast Cd was estimated using data from Fig. 1. The amounts of $\mathrm{Cd}^{2+}$ in the symplast that could form complexes with phytochelatins $\left(\mathrm{PC}_{2-4}\right)$ and monothiols (Cys, $\gamma$-EC and GSH) were calculated assuming that all of the $\mathrm{Cd}$ in the symplast was in the $\mathrm{Cd}^{2+}$ form and all thiol groups were available to interact with all $\mathrm{Cd}^{2+}$ ions. The thiol/ $\mathrm{Cd}^{2+}$ stoichiometries used were 1:1, 1:2 and 1:3 for the monothiols- $\mathrm{Cd}^{2+}, \mathrm{PC}_{2}-\mathrm{Cd}^{2+}$, and $\mathrm{PC}_{3-4}-\mathrm{Cd}^{2+}$ complexes, respectively. Barley and lettuce were grown with 0 or $1.0 \mu \mathrm{M}$ $\mathrm{CdCl}_{2}$ for $28 \mathrm{~d}$. Half of the plants grown with Cd were transferred to $5.0 \mathrm{mM} \mathrm{CdCl}_{2}$ for $1 \mathrm{~h}$ immediately prior to harvest. Molar amounts are mean (SE), $\mathrm{n}=3$ for each treatment, $\mathrm{dl}=$ detection limit.

\begin{tabular}{|c|c|c|c|c|c|c|c|}
\hline Species & $\begin{array}{l}\text { Cd } \\
\text { treatment }\end{array}$ & $\begin{array}{l}\text { Total root } \\
\text { Cd }(\mu \mathrm{mol})\end{array}$ & $\begin{array}{l}\text { Symplast Cd } \\
(\mu \mathrm{mol})\end{array}$ & $\begin{array}{l}\mathrm{Cd}^{2+} \\
\text { chelated by } \\
\text { PCs }(\mu \mathrm{mol})\end{array}$ & $\begin{array}{l}\% \mathrm{Cd}^{2+} \\
\text { chelated } \\
\text { by PCs }\end{array}$ & $\begin{array}{l}\text { Total } \mathrm{Cd}^{2+} \\
\text { chelated by } \\
\text { monothiols and } \\
\text { PCs ( } \mu \text { mol) }\end{array}$ & $\begin{array}{l}\% \mathrm{Cd}^{2+} \text { chelated } \\
\text { by monothiols } \\
\text { and PCs }\end{array}$ \\
\hline \multirow{3}{*}{ Barley } & No Cd & $0.03(0.01)$ & $0.01(0.01)$ & 0 & 0 & $2.83(0.42)$ & 100 \\
\hline & $1.0 \mu \mathrm{M}$ & $3.99(0.32)$ & $2.15(0.17)$ & $3.66(0.34)$ & 100 & $6.68(0.63)$ & 100 \\
\hline & $5.0 \mathrm{mM}$ & 20.69 (3.27) & 11.17 (1.77) & $5.12(0.53)$ & 45.8 & $9.48(0.83)$ & 84.9 \\
\hline \multirow{3}{*}{ Lettuce } & No Cd & $<\mathrm{dl}$ & $<\mathrm{dl}$ & 0 & 0 & $0.57(0.06)$ & 100 \\
\hline & $1.0 \mu \mathrm{M}$ & $0.58(0.11)$ & $0.20(0.03)$ & 0 & 0 & $0.46(0.10)$ & 100 \\
\hline & $5.0 \mathrm{mM}$ & $26.97(2.84)$ & $9.30(0.98)$ & 0 & 0 & $0.49(0.004)$ & 5.3 \\
\hline
\end{tabular}



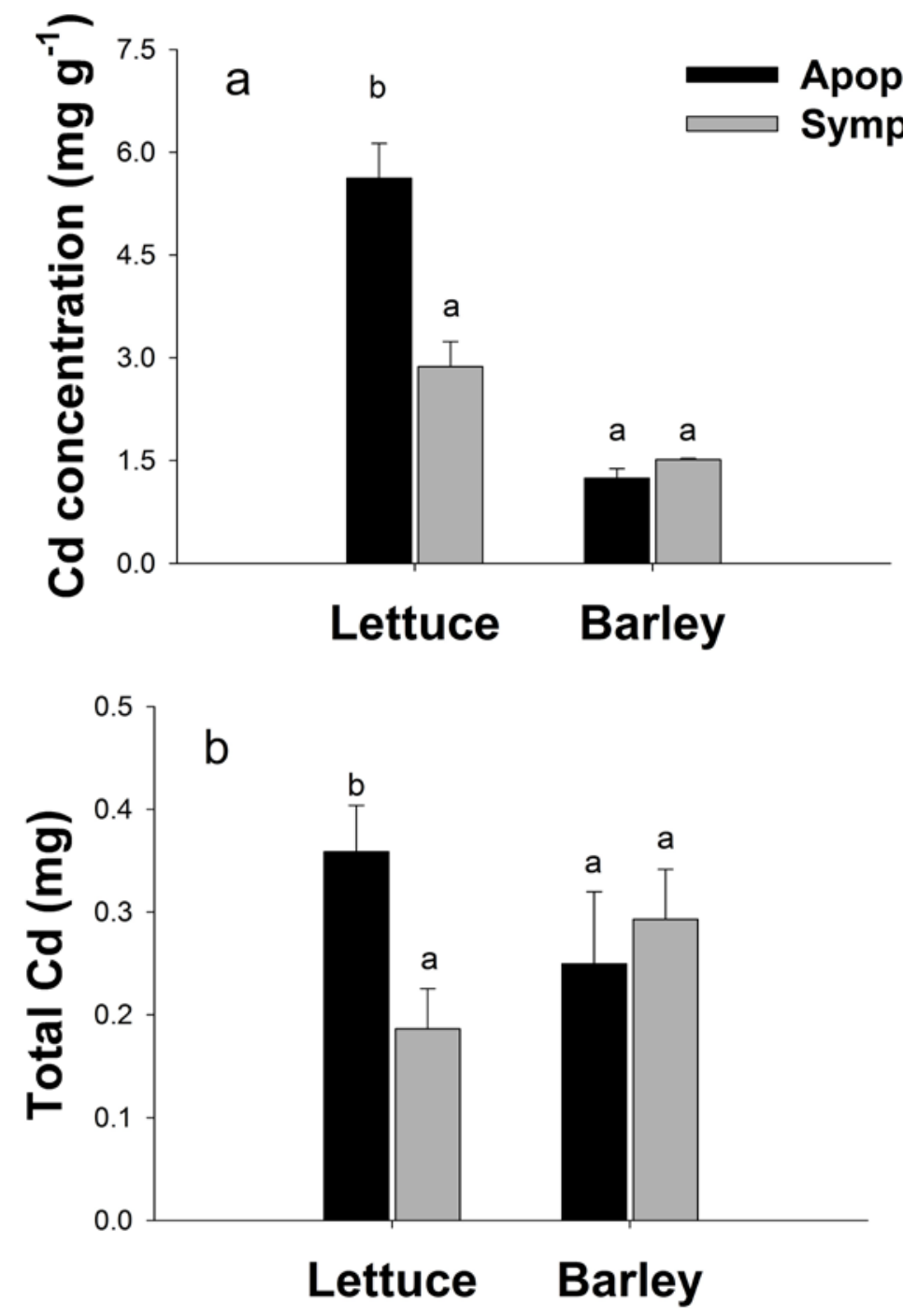

Fig. 1. (a) Concentration ( $\mathrm{mg} \mathrm{g}^{-1}$ ) and (b) total amount (mg) of Cd in the apoplast and symplast compartments in lettuce and barley root. The plants were grown in $1.0 \mu \mathrm{M} \mathrm{CdCl} 2$ for $28 \mathrm{~d}$ before exposed to $5.0 \mathrm{mM} \mathrm{CdCl}_{2}$ for $1 \mathrm{~h}$ at harvest. Within each species, different lower case letters indicate significant differences in Cd accumulation, as determined by one-way ANOVA and post hoc Tukey tests $(p<0.05)$. 


\begin{tabular}{|c|c|c|c|c|c|c|c|c|}
\hline & \multicolumn{2}{|c|}{$\mathrm{Cd}$} & \multirow[t]{2}{*}{ Barley } & & \multirow[t]{2}{*}{ Lettuce } & & \multicolumn{2}{|c|}{$\mathrm{Cd}$} \\
\hline & $1.0 \mu \mathrm{M}$ & $5 \mathrm{mM}$ & & & & & $1.0 \mu \mathrm{M}$ & $5 \mathrm{mM}$ \\
\hline Cys & $\downarrow$ & $=$ & & & & Cys & $\downarrow \downarrow$ & $\downarrow \downarrow$ \\
\hline$\gamma-\mathbf{E C}$ & $=$ & $=$ & & & & $\gamma-\mathbf{E C}$ & $<$ dl & $<$ dl \\
\hline GSH & $\downarrow \downarrow$ & $=$ & & & & GSH & $\downarrow \downarrow$ & $\downarrow \downarrow$ \\
\hline $\mathrm{PC}_{2}$ & $<$ dl & $<$ dl & & & & $\mathbf{P C}_{2}$ & $<$ dl & $<$ dl \\
\hline $\mathrm{PC}_{3}$ & $<$ dl & $<$ dl & & Shoot & & $\mathrm{PC}_{3}$ & $<$ dl & $<$ dl \\
\hline $\mathrm{PC}_{4}$ & $\downarrow \downarrow$ & $=$ & & & & $\mathrm{PC}_{4}$ & $\downarrow \downarrow$ & $\uparrow \uparrow$ \\
\hline & \multicolumn{2}{|c|}{$\mathrm{Cd}$} & & & & & \multicolumn{2}{|c|}{$\mathrm{Cd}$} \\
\hline & $1.0 \mu \mathrm{M}$ & $5 \mathrm{mM}$ & & Root & & & $1.0 \mu \mathrm{M}$ & $5 \mathrm{mM}$ \\
\hline Cys & $\bar{c}_{\uparrow \uparrow \uparrow}$ & $\bar{u}_{\uparrow \uparrow \uparrow \uparrow}$ & & & & Cys & $=$ & $=$ \\
\hline$\gamma-\mathbf{E C}$ & $\uparrow \uparrow \uparrow$ & $\uparrow \uparrow \uparrow$ & & & & $\gamma-\mathbf{E C}$ & $<$ dl & $<\mathrm{dl}$ \\
\hline GSH & $=$ & $=$ & & & & GSH & $\downarrow \downarrow$ & $=$ \\
\hline $\mathrm{PC}_{2}$ & $\uparrow \uparrow \uparrow$ & $\uparrow \uparrow \uparrow$ & & & & $\mathrm{PC}_{2}$ & $<$ dl & $<\mathrm{dl}$ \\
\hline $\mathrm{PC}_{3}$ & $\uparrow$ & $\uparrow$ & & & & $\mathrm{PC}_{3}$ & $<$ dl & $<\mathrm{dl}$ \\
\hline $\mathrm{PC}_{4}$ & $\uparrow$ & $\uparrow$ & & & & $\mathrm{PC}_{4}$ & $<$ dl & $<\mathrm{dl}$ \\
\hline
\end{tabular}

Fig. 2. Schematic presentation of the relative changes in molar amounts of phytochelatins $\left(\mathrm{PC}_{2}\right.$, $\mathrm{PC}_{3}$, and $\left.\mathrm{PC}_{4}\right)$ and their precursor monothiols (Cys, $\gamma$-EC, and $\mathrm{GSH}$ ) in plants from the two $\mathrm{Cd}$ treatments relative to the corresponding control plants, as reported in Table 4. Within each species, = indicates no change relative to control, upward and downward arrows indicate increases and decreases relative to control, respectively. One arrow indicates a change in the order of $30-45 \%$, two arrows indicate a change in the order of 50\%, three arrows indicate a change of about $100 \%$ and four arrows indicate a change of about $500 \%$, < dl indicates below detection limit. 


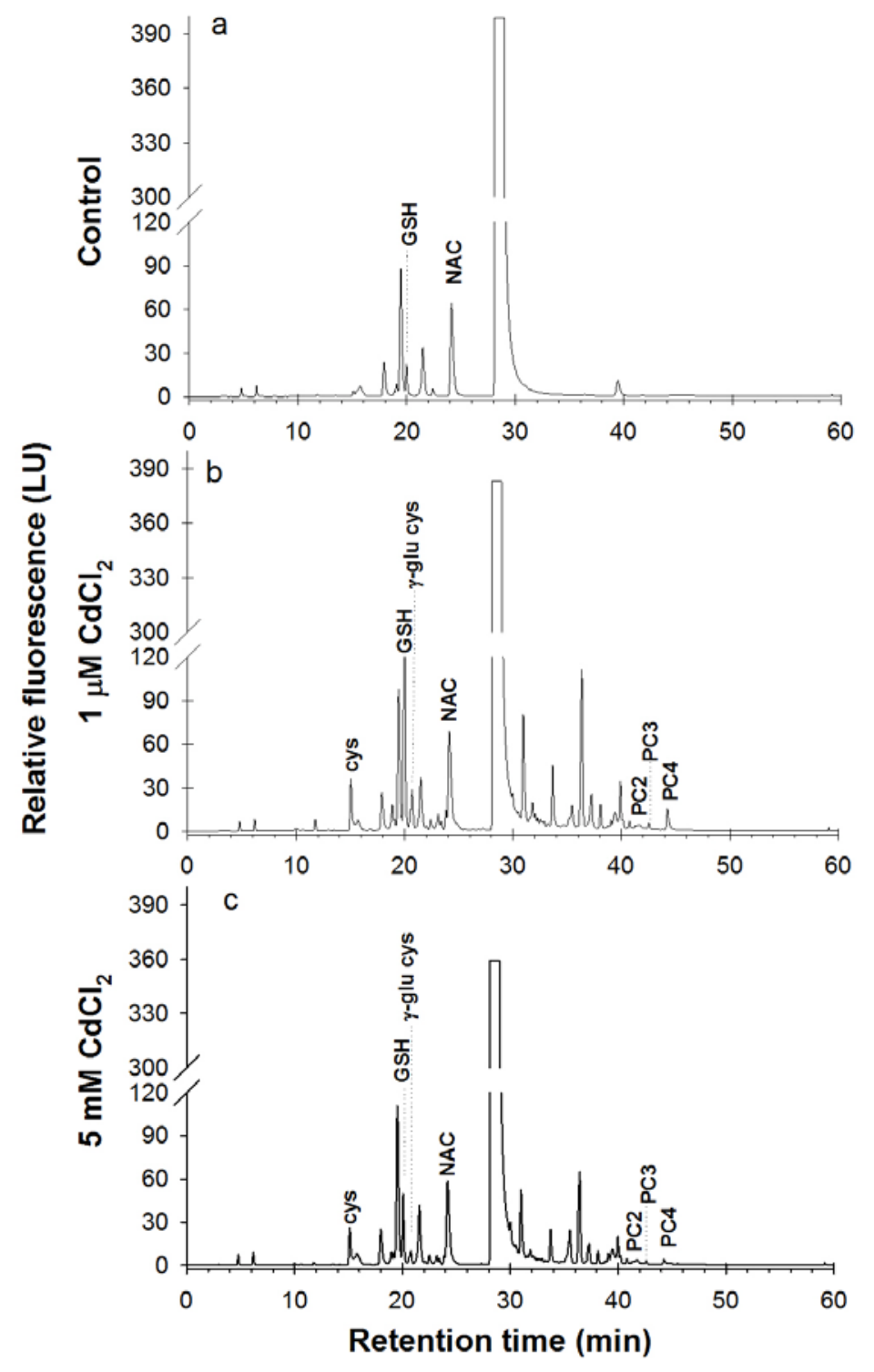

Fig. S1. Cadmium exposure results in the appearance of $\mathrm{PCs}\left(\mathrm{PC}_{2}, \mathrm{PC}_{3}\right.$, and $\left.\mathrm{PC}_{4}\right)$ and precursor monothiols (cys, $\gamma$-EC, and GSH) in the root extract of barley. Thiols from (a) control and plants exposed to (b) $1.0 \mu \mathrm{M} \mathrm{CdCl}_{2}$ for $28 \mathrm{~d}$, and (c) $5.0 \mathrm{mM} \mathrm{CdCl}_{2}$ for $1 \mathrm{~h}$ at harvest were derivatized with monobromobimane, separated by size exclusion HPLC and detected by fluorescence. 


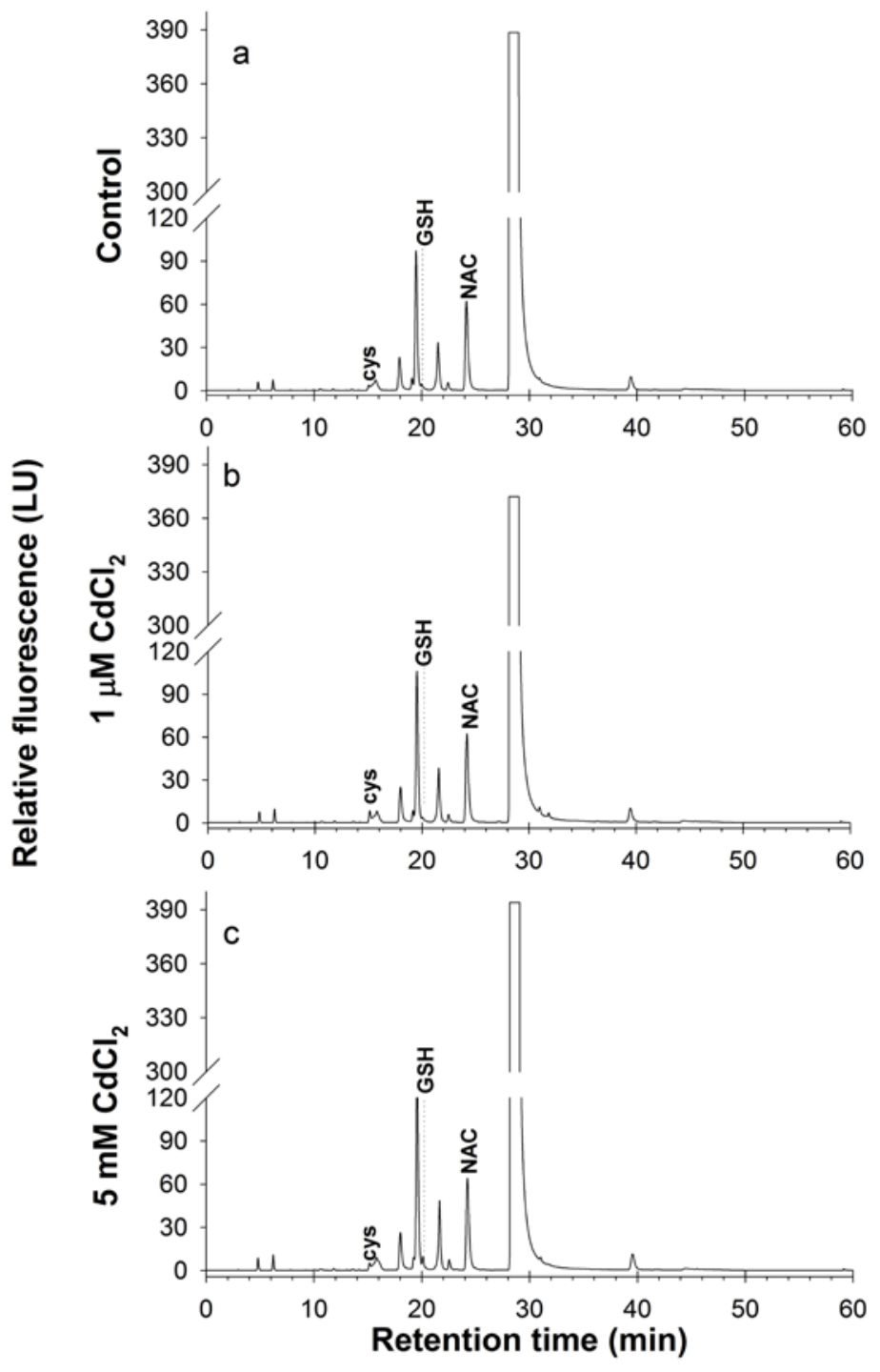

Fig. S2. Cadmium exposure results in the appearance of precursor monothiols only (cys, $\gamma$-EC, and GSH) in the root extract of lettuce. Thiols from (a) control and plants exposed to (b) $1.0 \mu \mathrm{M}$ $\mathrm{CdCl}_{2}$ for $28 \mathrm{~d}$, and (c) $5.0 \mathrm{mM} \mathrm{CdCl}$ for $1 \mathrm{~h}$ at harvest were derivatized with monobromobimane, separated by size exclusion HPLC and detected by fluorescence. 